Studia nad Autorytaryzmem i Totalitaryzmem 43, nr 3

Wrocław 2021

https://doi.org/10.19195/2300-7249.43.3.10

\author{
KAROLINA STOPKA \\ Uniwersytet Wrocławski \\ ORCID: 0000-0003-1199-9350 \\ karolina.stopka@uwr.edu.pl
}

\title{
Świadczenia dla działaczy opozycji antykomunistycznej i osób represjonowanych z powodów politycznych
}

Słowa kluczowe: zabezpieczenie społeczne, odszkodowanie socjalne, działacz opozycji antykomunistycznej, osoba represjonowana.

\section{BENEFITS FOR ANTI-COMMUNIST OPPOSITIONISTS AND PEOPLE REPRESSED FOR POLITICAL REASONS}

\begin{abstract}
The purpose of the study is to present the benefits for anti-communist opposition activists and persons repressed because of anti-communist activity normalized in the Act of 20 March 2015 on anti-communist opposition activists and persons repressed for political reasons. The regulation is a relatively new manifestation of the state's historical and social policy in the field of social security of citizens fighting for the sovereignty and independence of the homeland, not discussed in much detail in the literature.

As part of the introductory remarks, the paper points out the place of benefits for "oppositionists" in the social security system, their constitutional conditions, as well as the motives and goals that guided the legislator while passing the law. In the further part of the study, the subject and object scope of these benefits were indicated, particularly the criteria based on which notions of anti-communist opposition activist and person repressed for political reasons were defined. It was stressed that some manifestations of "opposition" activity are at the same time elements defining other categories of persons involved in the fight for sovereignty and independence of the homeland and that personal injury (its concrete form), as a rule, is not a constructional element of these concepts. Due to the limited scope of the study, only the legal regulation of financial benefits for "oppositionists" was analyzed in more detail. The description takes into account changes in the legal regulation of their catalog and the conditions of their use. The article assesses the adequacy of the adopted
\end{abstract}


legal solutions to the assumed objectives of the benefits and comments formulated in the analysis of the concept of anti-communist opposition activist and person repressed for political reasons.

The analysis leads to the conclusion that in the current legal state, the benefits for "oppositionists" are an expression of the legislator's aspiration to exclude them from the group of social assistance recipients and to guarantee them support taking into account their merits for Poland. This support is a form of specific - "tailored to meet the needs of social security and the financial capabilities of the state" - partial compensation of damages, including those caused by the opposition, as well as non-material damage, even though its specific forms do not directly determine the subjective and objective prerequisites for determining the right to benefits. However, the omission of the family members of a deceased "oppositionist" from the group of entities entitled to benefits was regarded as dubious.

Keywords: social security, social compensation, activist of the anti-communist opposition, repressed person.

\section{Uwagi wstępne}

Współczesne systemy świadczeniowe zabezpieczenia społecznego koncentrują się na ochronie socjalnej jednostki na wypadek zdarzeń losowych, które mogą wyniknąć w przyszłości, stanowiąc typowy element życia zawodowego, rodzinnego oraz społecznego jednostki. Wśród świadczeń zabezpieczenia społecznego stosunkowo liczną grupę, i wbrew pozorom trwałą, tworzą również świadczenia kompensujące następstwa śmierci lub naruszenia dobrostanu fizycznego, psychicznego czy społecznego jednostki, związane z wydarzeniami historycznymi, ujmowane w rozważaniach teoretycznych nad prawem zabezpieczenia społecznego - jego partycją w kategorii świadczeń odszkodowania socjalnego. Świadczenia te mają w polskim ustawodawstwie stosunkowo długą tradycję ${ }^{1}$, choć dopiero demokratyzacja stosunków społecznych oraz przywrócenie godności ludzkiej należytej jej rangi wyzwoliły objęcie w większym zakresie ochroną osób, które doznały szkód na osobie na skutek zdarzeń zaszłych ${ }^{2}$. W aktualnym stanie prawnym poza świadczeniami związanymi z drugą wojną światową i okresem powojennym, adresowanymi do inwalidów wojennych ${ }^{3}$, kombatantów, osób

1 Więcej zob. K. Stopka, Świadczenia odszkodowania socjalnego w prawie polskim, Warszawa 2018, s. 55. Zob. także J.P. Sobolewski, Prawo kombatanckie w Polsce i za granica, Warszawa 2005, s. 16-26 i przywołana tam literatura; oraz Zarys problematyki prawa kombatanckiego i organizacji kombatanckich w II Rzeczypospolitej, Kancelaria Senatu Biuro Analiz i Dokumentacji, Dział Analiz i Opracowań Tematycznych, Opracowania Tematyczne OT-586, lipiec 2010, www.se nat.gov.pl.

${ }^{2}$ H. Szurgacz, Prawo socjalne w latach 1989-1999. Kilka uwag o kierunkach rozwoju, [w:] Prawo pracy a wyzwania XXI w. Księga Jubileuszowa Profesora Tadeusza Zielińskiego, red. M. Matey-Tyrowicz, L. Lawacki, B. Wagner, Warszawa 2002, s. 528. Zob. także H.F. Zacher, Rozwój zabezpieczenia spolecznego w Europie, [w:] Lad spoleczny w Polsce i Niemczech na tle jednoczacej się Europy, red. M. von Bernd, T. Zieliński, Warszawa 1999, s. 379 n.

${ }^{3}$ Ustawa z dnia 29 maja 1974 r. o zaopatrzeniu inwalidów wojennych i wojskowych oraz członków ich rodzin, tekst jedn. Dz.U. z 2021 r. poz. 1656. 
będących ofiarami represji wojennych i okresu powojennego ${ }^{4}$, osób skierowanych do pracy przymusowej oraz osadzonych w obozach pracy ${ }^{5}$ czy niewidomych cywilnych ofiar wojny ${ }^{6}$, obejmują one także świadczenia związane $\mathrm{z}$ walką o demokratyzację stosunków społecznych, to jest świadczenia adresowane do ofiar wystąpień wolnościowych w latach 1956-1989, osób internowanych w okresie stanu wojennego i członków ich rodzin ${ }^{7}$, a od 2015 roku również działaczy opozycji antykomunistycznej i osób represjonowanych z powodów politycznych.

Zasadność i potrzeba zapewnienia jednostce socjalnego bezpieczeństwa w razie szkód na osobie związanych ze zdarzeniami historycznymi ma umocowanie $\mathrm{w}$ wartościach wyrażonych $\mathrm{w}$ ustawie zasadnicznej — nie tylko w ideach i dobrach wprost określonych tym mianem, a więc w postanowieniach Konstytucji RP je promujących, zawartych przede wszystkim w preambule, lecz także w normach materialnoprawnych, zawartych w pozostałych jej częściach ${ }^{8}$. Wśród tak rozumianych wartości konstytucyjnych potrzebę zapewnienia jednostce bezpieczeństwa socjalnego na wypadek szkód na osobie mających związek ze zdarzeniami historycznymi uzasadniają, poza solidarnością, z której wyprowadzić można zbiorową odpowiedzialność wobec jednostki za to, co leży w interesie innych ludzi ${ }^{9}$, takie dobra, jak: walka o niepodległość, możliwość suwerennego i demokratycznego stanowienia przez naród o losie ojczyzny. Na dobra te Konstytucja wskazuje w preambule, wyrażając wdzięczność przodkom za „walkę o niepodległość okupioną ogromnymi ofiarami” oraz wskazując na pamięć „,gorzkich doświadczeń z czasów, gdy podstawowe wolności i prawa człowieka były w naszej Ojczyźnie łamane". Do dóbr tych nawiązuje też w zasadzie ustrojowej

${ }^{4}$ Ustawa z dnia 24 stycznia 1991 r. o kombatantach oraz niektórych osobach będących ofiarami represji wojennych i okresu powojennego, tekst jedn. Dz.U. z 2021 r. poz. 1858 (dalej: ustawa o kombatantach).

${ }^{5}$ Ustawa z dnia 31 maja 1996 r. o świadczeniu pieniężnym przysługującym osobom deportowanym do pracy przymusowej oraz osadzonym w obozach pracy przez III Rzeszę i Związek Socjalistycznych Republik Radzieckich, tekst jedn. Dz.U. z 2021 r. poz. 1818; oraz ustawa z dnia 2 września 1994 r. o świadczeniu pieniężnym i uprawnieniach przysługujących żołnierzom zastępczej służby wojskowej przymusowo zatrudnianym w kopalniach węgla, kamieniołomach, zakładach rud uranu i batalionach budowalnych, tekst jedn. Dz.U. z 2021 r. poz. 1774. Zob. także R. Klementowski, Skazani na uran. Kopalnie rud uranu we wspomnieniach żotnierzy batalionów pracy, „Studia nad Autorytaryzmem i Totalitaryzmem" 31, 2009, s. 293-307.

${ }^{6}$ Ustawa z dnia 16 listopada 2006 r. o świadczeniu pieniężnym i uprawnieniach przysługujących cywilnym niewidomym ofiarom działań wojennych, tekst jedn. Dz.U. z 2021 r. poz. 794.

7 Ustawa z dnia 7 maja 2009 r. o zadośćuczynieniu rodzinom ofiar zbiorowych wystąpień wolnościowych w latach 1956-1989, tekst jedn. Dz.U. z 2020, poz. 678.

${ }^{8} \mathrm{Na}$ takie rozumienie wartości konstytucyjnych uprzednio zwracał uwagę Z. Ziembiński, Wartości konstytucyjne. Zarys problematyki, Warszawa 1993, s. 36-56; wśród przedstawicieli doktryny prawa zabezpieczenia społecznego W. Sanetra, Aksjologiczne podstawy prawa ubezpieczeń społecznych, [w:] Ubezpieczenie społeczne procesie zmian. 80 lat Zakładu Ubezpieczeń Społecznych, Warszawa 2014, s. 29-32.

9 Zob. L. Rodak, Solidaryzm i/jako obiektywizm, [w:] Idea solidaryzmu we wspótczesnym prawie konstytucyjnym, red. A. Łabno, Warszawa 2015, s. 22-44. 
specjalnej opieki nad weteranami walk o niepodległość, zwłaszcza inwalidami wojennymi (art. 19) ${ }^{10}$. Na uwarunkowanie świadczeń zabezpieczenia społecznego związanych z wydarzeniami historycznymi wymienionymi tu dobrami wskazują też preambuły niektórych aktów je normujących, zwłaszcza wskazywane w nich okoliczności społeczno-polityczne, będące podstawą ich genezy, motywów i celów regulacji prawnej.

Jak nadmieniono, najnowszym przejawem państwowej polityki historycznej i polityki społecznej w zakresie zabezpieczenia społecznego obywateli walczących o niepodległość ojczyzny jest ustawa z 20 marca 2015 roku o działaczach opozycji antykomunistycznej oraz osobach represjonowanych z powodów politycznych. Zgodnie z preambułą jest ona wyrazem uznania zasług dla Polski tych jej obywateli, którzy w latach 1956-1989 z narażeniem własnego życia, wolności, majątku lub praw pracowniczych angażowali się w działalność antykomunistyczną zmierzającą do odzyskania suwerenności i niepodległości ojczyzny lub byli $\mathrm{z}$ tych powodów represjonowani. Uzasadnienie zaś do projektu ustawy wskazuje, że unormowane w niej świadczenia są próbą zaradzenia zjawisku biedy i wykluczenia społecznego dotykającego środowisko działaczy opozycji antykomunistycznej ${ }^{11}$. Ustawa w okresie niespełna sześcioletniego obowiązywania była kilkakrotnie nowelizowana. $Z$ perspektywy przedmiotu opracowania najistotniejsze znaczenie miały nowele $\mathrm{z}$ roku $2017^{12}, 2019^{13}$ oraz $2020^{14}$. Zmodyfikowały one zasady przyznawania świadczeń oraz rozszerzyły ich pierwotny katalog.

\section{Pojęcie działacza opozycji antykomunistycznej i osoby represjonowanej z powodów politycznych}

Definicje działacza opozycji antykomunistycznej oraz osoby represjonowanej z powodów politycznych oparto na kryterium biograficznym, obejmującym

10 Więcej K. Stopka, Świadczenia odszkodowania..., s. 65-73, 75-76. Na temat prawa do specjalnej opieki weteranów walk o niepodległość obszernie K. Ślebzak, Prawo do zabezpieczenia społecznego w Konstytucji RP. Zagadnienia podstawowe, Warszawa 2015, s. 69-75 i przywołane tam piśmiennictwo.

11 Uzasadnienie do projektu ustawy o działaczach opozycji antykomunistycznej, Sejm VII kadencji, druk nr 2137.

12 Ustawa z dnia 8 czerwca 2017 r. o zmianie ustawy o działaczach opozycji antykomunistycznej oraz osobach represjonowanych z powodów politycznych oraz niektórych innych ustaw, Dz.U. z 2017 r. poz. 1386 (art. 1).

13 Ustawa z dnia 15 marca 2019 r. o zmianie ustawy o kombatantach oraz niektórych osobach będących ofiarami represji wojennych i okresu powojennego oraz niektórych innych ustaw, Dz.U. z 2019 r. poz. 752 (art. 12).

14 Ustawa z dnia 14 sierpnia 2020 r. o zmianie ustawy o działaczach opozycji antykomunistycznej oraz osobach represjonowanych z powodów politycznych oraz niektórych innych ustaw, Dz.U. z 2020 r. poz. 1578 (art. 1). 
przesłanki pozytywne oraz negatywne. Przy czym pojęcie działacza opozycji antykomunistycznej ustawa łączy z prowadzeniem działalności w warunkach i celu wyraźnie w niej określonym, a pojęcie osoby represjonowanej z powodów politycznych, z określonymi dolegliwościami ze strony ówczesnych organów państwa $^{15}$. De facto nie wszystkie przejawy walki, sprzeciwu czy oporu społecznego względem dawnego ustroju, jak też nie wszystkie przejawy represji ze strony organów władzy, w wymiarze ogólnym czy indywidualnym, umożliwiają przyznanie statusu działacza opozycji antykomunistycznej lub osoby represjonowanej z powodów politycznych ${ }^{16}$. Jednocześnie $\mathrm{w}$ judykaturze wskazuje się, że pojęcia te nie mają charakteru rozłącznego, co oznacza możliwość jednoczesnego uznania danej osoby za działacza opozycji antykomunistycznej i osobę represjonowaną z powodów politycznych ${ }^{17}$.

Według ustawy za działacza opozycji antykomunistycznej uznaje się osobę, która w okresie od 1 stycznia 1956 roku do 4 czerwca 1989 roku, łącznie przez co najmniej 12 miesięcy, prowadziła, w ramach struktur zorganizowanych lub we współpracy z nimi, zagrożoną odpowiedzialnością karną, działalność na rzecz odzyskania przez Polskę niepodległości i suwerenności lub respektowania politycznych praw człowieka w Polsce. Do okresu działalności antykomunistycznej nie wlicza się okresów działalności w ramach niezależnego ruchu związkowego lub niezależnego ruchu studenckiego, prowadzonej w okresie od 31 sierpnia 1980 roku do 12 grudnia 1981 roku (art. 2).

Status osoby represjonowanej z powodów politycznych ustawa przyznaje natomiast osobie, która w okresie od 1 stycznia 1956 roku do 31 lipca 1990 roku:

1. za działalność na rzecz odzyskania przez Polskę niepodległości i suwerenności lub respektowania politycznych praw człowieka w Polsce:

a) przebywała w więzieniu lub innym miejscu odosobnienia na terytorium Polski na mocy wyroku wydanego w latach 1956-1989 albo bez wyroku jednorazowo przez okres dłuższy niż 48 godzin lub wielokrotnie przez łączny okres dłuższy niż 30 dni albo w ośrodku odosobnienia na podstawie przepisów o stanie wojennym,

b) przez okres powyżej 30 dni pełniła zasadniczą służbę wojskową lub czynną służbę wojskową w ramach ćwiczeń wojskowych oraz

c) była poszukiwana listem gończym, oskarżona lub skazana za popełnienie przestępstwa lub wielokrotnie skazywana za popełnienie wykroczenia, a także

2. osobie, która brała udział w wystąpieniu wolnościowym na rzecz odzyskania przez Polskę niepodległości i suwerenności lub respektowania politycznych praw człowieka w Polsce i w związku z tym:

15 Zob. wyrok WSA w Gorzowie Wielkopolskim z dnia 22 stycznia 2020 r., II SA/Go 447/19, LEX nr 2775510.

16 Tak np. wyrok WSA we Wrocławiu z dnia 17 października 2019 r., IV SA/Wr 172/19, LEX nr 2742413.

17 Wyrok WSA w Łodzi z dnia 23 października 2019, II SA/Łd 427/19, LEX nr 2741081. 
a) na skutek działania, w tym niejawnego, wojska, milicji lub organów bezpieczeństwa państwa, poniosła śmierć, doznała uszkodzenia ciała lub rozstroju zdrowia na okres dłuższy niż 7 dni,

b) była inwigilowana przez organy bezpieczeństwa państwa i podjęto wobec niej bezprawne działanie polegające na popełnieniu na jej szkodę przestępstwa lub wykroczenia,

c) była pozbawiona możliwości wykonywania swojego zawodu,

d) została $\mathrm{z}$ nią rozwiązana umowa o pracę,

e) została relegowana $z$ uczelni wyższej lub innej szkoły lub

f) była objęta zakazem publikacji przez okres dłuższy niż jeden rok (zob. art. 3).

Uzyskanie statusu działacza opozycji antykomunistycznej oraz osoby represjonowanej z przyczyn politycznych wyklucza, co do zasady, bycie pracownikiem, funkcjonariuszem lub żołnierzem organów bezpieczeństwa państwa lub współpraca $\mathrm{z}$ nimi w charakterze tajnego informatora lub pomocnika przy operacyjnym zdobywaniu przez nie informacji, znajdująca potwierdzenie w dokumentach zachowanych w archiwum Instytutu Pamięci Narodowej - Komisji Ścigania Zbrodni przeciwko Narodowi Polskiemu (zob. art. 4).

Status działacza opozycji antykomunistycznej lub osoby represjonowanej potwierdza decyzją administracyjną Szef Urzędu do Spraw Kombatantów i Osób Represjonowanych, na wniosek działacza, osoby represjonowanej, wdowy lub wdowca po nim lub innego członka rodziny zmarłego (zob. art. 5).

Na koniec tej części rozważań dodać należy, że niektóre przejawy działalności opozycyjnej z lat 1956-1989 wskazane w tych przepisach są jednocześnie elementem definiującym inne kategorie osób zaangażowanych $\mathrm{w}$ działalność opozycyjną, będących podmiotem odrębnie uregulowanych świadczeń. Przykładowo ustawa o kombatantach, która za kombatantów uznaje osoby biorące udział w wojnach, działaniach zbrojnych i powstaniach narodowych, wchodząc w skład formacji wojskowych lub organizacji walczących o suwerenność i niepodległość Rzeczypospolitej Polskiej (art. 1 ust. 1 ustawy kombatanckiej), za działalność równorzędną z działalnością kombatancką lub za podleganie represjom wojennym i okresu powojennego uznaje jednocześnie między innymi czynny udział w zbrojnym wystąpieniu o wolność i suwerenność Polski w Poznaniu w czerwcu 1956 roku, który skutkował śmiercią lub uszczerbkiem na zdrowiu oraz poniesieniem śmierci, uszkodzeniem ciała lub rozstrojem zdrowia powyżej siedmiu dni w grudniu 1970 roku na Wybrzeżu wskutek działania wojska lub milicji podczas wystąpień wolnościowych (art. 2 pkt 5-6 ustawy kombatanckiej).

Dla dalszych rozważań istotna jest też konstatacja, że co do zasady szkoda na osobie nie jest elementem konstrukcyjnym definicji działacza opozycji antykomunistycznej oraz osoby represjonowanej z powodów politycznych. Z tych uregulowań wynika, że szkoda na osobie jest wprost elementem konstrukcyjnym wyłącznie pojęcia osoby represjonowanej z powodów politycznych, przejawiającej 
się udziałem w wystąpieniach wolnościowych. Z tej perspektywy okoliczności uprawniające do uzyskania statusu działacza opozycji antykomunistycznej lub osoby represjonowanej wypada łączyć generalnie z niemajątkowymi przejawami szkody na osobie w postaci cierpień fizycznych i psychicznych. Bez wątpienia działalność antykomunistyczna, związane z nią represje i szykany były u osób w nią zaangażowanych źródłem cierpień, które w wielu przypadkach wywarły lub nadal wywierają wpływ na ich zaradność życiową, i dotykającego ich przez wiele lat zjawiska biedy i wykluczenia społecznego, o którym wzmiankowano w uzasadnieniu do projektu ustawy.

\section{Warunki nabycia prawa do świadczeń i korzystania $\mathrm{z}$ nich}

Aktualnie ustawa przewiduje trzy rodzaje wsparcia finansowego na rzecz osób, wobec których potwierdzony zostanie status działacza opozycji antykomunistycznej lub osoby represjonowanej: świadczenie pieniężne, jednorazową lub okresową pomoc pieniężną oraz świadczenie wyrównawcze. Przed nowelą z 2020 roku ustawa przewidywała tylko pierwsze dwa świadczenia. Do noweli z 2017 roku korzystanie z nich uwarunkowane było, co do zasady, spełnieniem kryterium dochodowego będącego określonym procentem najniższej emerytu$\mathrm{ry}^{18}$. Obecnie kryterium dochodowe warunkuje przyznanie wyłącznie prawa do pomocy pieniężnej. Poza tym ustawa przyznała działaczom opozycji antykomunistycznej i osobom represjonowanym prawo pierwszeństwa do środowiskowej opieki socjalnej, w tym prawo pierwszeństwa w uzyskaniu miejsca w domu pomocy społecznej, a w następstwie noweli z 2020 roku również prawo do ulg taryfowych przy przejazdach środkami komunikacji miejskiej oraz komunikacji krajowej. Ze względu na ograniczone ramy opracowania obszerniej omówione zostaną wyłącznie świadczenia pieniężne. Warto nadmienić, że mimo przewidzianej w przepisach ustawy możliwości potwierdzenia statusu działacza opozycji antykomunistycznej lub osoby represjonowanej z powodów politycznych na wniosek członka rodziny zmarłego „opozycjonisty” ustawa nie czyni członków jego rodziny podmiotem prawa do jakichkolwiek świadczeń. Ten stan rzeczy tłumaczy tylko poniekąd regulacja ustawy z 7 maja 2009 roku o zadośćuczynieniu rodzinom ofiar zbiorowych wystąpień wolnościowych w latach 1956-1989, która celem wynagrodzenia rodzinom ofiar wystąpień wolnościowych krzywd doznanych w związku ze śmiercią ich bliskich oraz ich wspomożenia ${ }^{19}$ przyznała

18 Por. art. 7 w zw. z art. 9 ust. 1 i art. 10 ust. 3 i 7 ustawy o działaczach opozycji antykomunistycznej w brzmieniu sprzed 31 sierpnia $2017 \mathrm{r}$.

19 Zob. preambuła do tej ustawy oraz uzasadnienie do jej projektu, druk nr 1510. 
każdemu uprawnionemu członkowi rodziny prawo do jednorazowego świadczenia pieniężnego w wysokości 50 tys. zł.

Świadczenie pieniężne w założeniu projektodawców ma pełnić funkcję świadczenia rentowego o charakterze stałym ${ }^{20}$. Wbrew pierwotnym założeniom przysługuje wszystkim uprawnionym w jednakowej wysokości niezależnej od ich indywidualnej sytuacji dochodowej ${ }^{21}$. Ryczałtowo określona w ustawie kwota świadczenia, wynosząca aktualnie 460,50 zł, jest zwiększana przy zastosowaniu wskaźnika waloryzacji emerytur i rent. Obecnie świadczenie pieniężne przyznaje się bezterminowo. Do 31 sierpnia 2017 roku świadczenie przyznawane było cyklicznie na okres 12 miesięcy. Wyjątkowo w wypadku osób, które ukończyły 67 lat, świadczenie mogło być przyznane na okres do 60 miesięcy, a w szczególnie uzasadnionych przypadkach na stałe. Po upływie okresu, na jaki przyznano świadczenie, osoba uprawniona mogła wystąpić z kolejnym wnioskiem o jego przyznanie $^{22}$.

Wobec częściowego pokrywania się zakresów podmiotowych ustawy oraz ustawy o kombatantach, co jak już wskazano, dotyczy osób biorących udział w wystąpieniach w czerwcu 1956 roku w Poznaniu oraz osób poszkodowanych w grudniu 1970 roku na Wybrzeżu, ustawa zawiera normę kolizyjną, przesądzającą, że osoba uprawniona, odnośnie do której status działacza opozycji antykomunistycznej lub osoby represjonowanej z powodów politycznych potwierdzały wyłącznie okoliczności i zdarzenia będące podstawą uprawnień kombatanckich, ma prawo wyboru reżimu prawnego przysługujących jej świadczeń. W konsekwencji według jej wyboru może korzystać z prawa do świadczenia pieniężnego albo prawa do dodatku kombatanckiego, świadczenia w wysokości dodatku kombatanckiego, ryczałtu energetycznego i dodatku kompensacyjnego, unormowanych w przepisach ustawy kombatanckiej (zob. art. 7).

W odróżnieniu od przedstawionego tu świadczenia pieniężnego pomoc pieniężna ma charakter fakultatywny oraz celowy, ukierunkowany na zaspokajanie określonych potrzeb, przykładowo tylko wymienionych przez ustawodawcę. Jest też zależna od kryterium dochodowego, a jej wysokość jest indywidualizowana. Obowiązujące zasady jej przyznawania ukształtowała nowela z 2019 roku. Świadczenie to adresowane jest do osób uprawnionych, znajdujących się w trudnej sytuacji materialnej, zdrowotnej lub w związku z zaistnieniem zdarzeń losowych (art. 10 ust. 1). Pomoc pieniężna jednorazowa może być przyznana w szczególności na pokrycie — w części lub całości — kosztów zakupu wyrobów medycznych oraz dostosowania pomieszczeń mieszkalnych do rodzaju niepełnosprawności (art. 10 ust. 2), a pomoc pieniężna okresowa może być przyznana w szczególności

${ }^{20}$ Uzasadnienie do projektu ustawy o działaczach opozycji antykomunistycznej, druk nr 2137.

21 Zob. senacki projekt ustawy o działaczach opozycji antykomunistycznej oraz osobach represjonowanych z powodów politycznych.

22 Por. art. 9 ustawy o działaczach opozycji antykomunistycznej w brzmieniu sprzed 31 sierpnia $2017 \mathrm{r}$. 
na zaspokojenie potrzeb bytowych i ochronę zdrowia w przypadku długotrwałej choroby powodującej wzrost kosztów utrzymania, zakupu leków, środków opatrunkowych oraz dojazdów do zakładów leczniczych na zabiegi medyczne i rehabilitacyjne oraz opłacenie pomocy pielęgnacyjnej niezbędnej ze względu na wiek oraz stan zdrowia (art. 10 ust. 3). Jak już wskazano, przyznanie tego świadczenia uwarunkowane jest kryterium dochodowym. Stanowi ono określony procent najniższej emerytury, zróżnicowany w zależności od rodzaju pomocy pieniężnej, prowadzenia przez osobę uprawnioną samodzielnego gospodarstwa domowego czy też stanu zdrowia uprawnionego. Tak uwarunkowane kryterium dochodowe wynosi $150-350 \%$ najniższej emerytury (zob. art. 10 ust. 4-5). Jednorazowa pomoc pieniężna przyznawana jest w wysokości do $150 \%$ najniższej emerytury, a odnośnie do potrzeb wskazanych wprost w ustawie, tu wymienionych, w wysokości, odpowiednio, do $350 \%$ i $450 \%$ tej emerytury. Okresowej pomocy pieniężnej udziela się natomiast, niezależnie od okoliczności uzasadniających jej udzielenie, każdorazowo w wysokości do 100\% najniższej emerytury. W myśl przepisów ustawy jednorazową pomoc pieniężną przyznaje się, co do zasady, nie częściej niż dwa razy w roku kalendarzowym, a pomoc okresową na okres do 6 miesięcy i nie częściej niż raz na 12 miesięcy. Jednocześnie ustawodawca zastrzega, że w szczególnie uzasadnionych przypadkach pomoc pieniężna może zostać przyznana na innych warunkach niż określone w ustawie (art. 10 ust. 10).

Poza tym ustawa $\mathrm{w}$ zakresie spraw związanych z przyznawaniem pomocy pieniężnej i świadczenia pieniężnego odsyła do odpowiedniego stosowania enumeratywnie wskazanych przepisów ustawy o pomocy społecznej ${ }^{23}$ (art. 11). Nie wchodząc w szczegóły, warto pokreślić, że z perspektywy warunków nabycia prawa do przedstawionych świadczeń przepisy, do których odpowiedniego stosowania ustawa odsyła, znajdą zastosowanie zwłaszcza do pomocy pieniężnej. Wobec tego jej marnotrawienie może stanowić podstawę do jej ograniczenia lub odmowy przyznania, a zmiana sytuacji dochodowej osoby będącej beneficjentem okresowej pomocy pieniężnej może powodować zmianę decyzji ustalającej prawo do niej na jej niekorzyść ${ }^{24}$. Warto również podkreślić, że wśród odpowiednio stosowanych przepisów ustawy o pomocy społecznej brakuje przepisów, które warunkowałyby prawo do tych świadczeń wykazaniem się przez osobę uprawnioną własnej aktywności w zakresie zaspokajania potrzeb życiowych, z jednej strony, z drugiej zaś uzależniały możliwość ich przyznania od sytuacji finansowej organu ${ }^{25}$.

23 Ustawa z dnia 12 marca 2004 r., tekst jedn. Dz.U. z 2020 r. poz. 1876 ze zm.

24 Art. 11 ustawy odsyła bowiem do odpowiedniego stosowania przepisów normujących skutki stwierdzenia przez organ marnotrawienia przyznanej pomocy (zob. art. 11 ust. 1 ustawy o pomocy społecznej) oraz uznających zmianę sytuacji dochodowej świadczeniobiorcy za obligatoryjną przesłankę weryfikacji decyzji ustalającej prawo do świadczenia na niekorzyść strony (zob. art. 106 ust. 3a i 5 ustawy o pomocy społecznej).

25 Por. np. art. 2 ust. 1, 3 ust. 4 oraz art. 4 w zw. z art. 11 ust. 2 ustawy o pomocy społecznej. Zob. także K. Stopka, Zasada subsydiarności w prawie pomocy społecznej, Warszawa 2009. 
Wobec tego świadczenia te, a zwłaszcza pomoc pieniężna, w której konstrukcji bez trudu dopatrzyć się można elementów charakterystycznych dla świadczeń z pomocy społecznej (uznaniowość, indywidualizacja, kryterium dochodowe, stan potrzeby $)^{26}$, nie są świadczeniami pomocy społecznej. Kwalifikację taką wyklucza wysokość kryterium dochodowego, od którego przepisy ustawy uzależniają nabycie prawa do pomocy pieniężnej. Jego wysokość istotnie odbiega od kryterium dochodowego warunkującego korzystanie ze świadczeń pomocy społecznej ${ }^{27} \mathrm{i}$ wskazuje, że pomoc pieniężna dla opozycjonistów z założenia nie ma mieć zastosowania do sytuacji zagrożenia ich bytu w wymiarze egzystencjalnym bądź obniżenia jakości ich życia poniżej społecznie akceptowanego minimum ${ }^{28}$.

Nowelą z 2020 roku wprowadzono do ustawy świadczenie wyrównawcze. W założeniu ustawodawcy ma ono na celu częściowe zrekompensowanie opozycjonistom ekonomicznych skutków represji doznanych w okresie PRL. Liczne szykany, którym w okresie 1956-1989 byli poddawani przez reżim komunistyczny, przez wiele lat rzutowały negatywnie na otrzymywane przez nich wynagrodzenie, skutkując obecnie pobieraniem przez nich niższych emerytur i rent. Kompensując świadczeniem wyrównawczym ekonomiczne skutki represji, ustawodawca dążył do choć częściowego zadośćuczynienia krzywdom doznanym ze strony reżimu komunistycznego ${ }^{29}$. Adekwatnie do celu nowelizacji prawo do świadczenia wyrównawczego przysługuje osobie pobierającej emeryturę, rentę inwalidzką, rentę z tytułu niezdolności do pracy albo rentę rodzinną w kwocie niższej niż 2450 zł i jako takie przysługuje w wysokości stanowiącej różnicę między tą kwotą a kwotą brutto pobieranej emerytury lub renty lub sumy tych świadczeń, w której nie uwzględnia się świadczeń wraz z nimi wypłacanych, na przykład dodatku pielęgnacyjnego (art. 10a ust. 1-3). Celem urealnienia wartości świadczenia wyrównawczego kwota uwzględniana przy obliczaniu świadczenia wyrównawczego jest podwyższana na zasadach właściwych waloryzacji emerytur i rent (art. 10a ust. 4). Istota świadczenia wyrównawczego uzasadniała przyznanie kompetencji do ustalania prawa do niego organom wypłacającym emeryturę lub rentę (zob. art. 10c), wypłacanie go wraz z emeryturą lub rentą (art. 10e), jak również odpowiednie stosowanie do niego w sprawach nieuregulowanych w ustawie przepisów ustawy o emeryturach i rentach z Funduszu Ubezpieczeń Społecznych (art. 10f). De lege ferenda wydaje się, że motywy leżące u podstaw wprowadzenia świadczenia wyrównawczego oraz jego charakter uzasadniały uczynienie podmiotem prawa do tego świadczenia $\mathrm{w}$ razie śmierci uprawnionego do niego

26 Zob. I. Sierpowska, Prawo pomocy społecznej, Kraków 2006, s. 68-71.

27 Por. art. 8 ust. 1 ustawy o pomocy społecznej. Zob. też H. Szurgacz, Wstęp do prawa pomocy społecznej, Wrocław 1992, s. 39.

${ }^{28}$ Zob. S. Nitecki, Prawo do pomocy społecznej w polskim systemie prawnym, Warszawa 2008, LEX.

${ }^{29}$ Uzasadnienie do rządowego projektu ustawy z dnia 14 sierpnia 2020 r. o zmianie ustawy o działaczach opozycji antykomunistycznej i osobach represjonowanych z powodów politycznych oraz niektórych innych ustaw, druk nr 535. 
„opozycjonisty” członków jego rodziny spełniających warunki wymagane do uzyskania po nim renty rodzinnej. Upraszczając, renta rodzinna jest świadczeniem na rzecz osób utrzymywanych przez zmarłego emeryta lub rencistę, wobec których ciążył na nim obowiązek alimentacyjny ${ }^{30}$, i jako taka stanowi określony procent emerytury lub renty zmarłego świadczeniobiorcy (,opozycjonisty”) ${ }^{31}$.

$\mathrm{Na}$ koniec warto dodać, że omówione tu świadczenia dla „opozycjonistów” finansowane są ze środków budżetu państwa (art. 10i i art. 16). Sposób ukształtowania tych świadczeń oraz brak przepisów regulujących zbieg prawa do nich wskazują na możliwość jednoczesnego korzystania z nich przez osobę uprawnioną.

\section{Uwagi końcowe}

Świadczenia unormowane w przepisach ustawy o działaczach opozycji antykomunistycznej i osobach represjonowanych z powodów politycznych nie mają jednolitego charakteru prawnego, jeśli patrzeć na nie z perspektywy natury uprawnień do korzystania z nich, kryteriów uprawniająco-ograniczających, wysokości czy okresu ich przysługiwania. Rodzaje świadczeń i warunki nabycia do nich prawa oraz ich modyfikacje, wskazują, że analizowana ustawa wyraża dążenie ustawodawcy do wyłączenia „opozycjonistów” z kręgu podopiecznych pomocy społecznej oraz zagwarantowania im wsparcia uwzględniającego ich zasługi dla Polski, będącego jednocześnie formą swoistego, częściowego wynagrodzenia szkód, w tym doznanych krzywd, na miarę zabezpieczenia społecznego i możliwości finansowych państwa. Nie oznacza to jednak, że regulacja przedstawionych świadczeń nie budzi wątpliwości. Krytycznie ocenić trzeba zwłaszcza pominięcie w grupie podmiotów uprawnionych do nich członków rodziny zmarłego „opozycjonisty”, uprawnionego do świadczenia wyrównawczego. Pominięcie to podaje W wątpliwość celowość dopuszczenia przez ustawodawcę możliwości potwierdzenia statusu działacza opozycji antykomunistycznej lub osoby represjonowanej z powodów politycznych na wniosek członków zmarłego „opozycjonisty”.

Uwarunkowanie prawa do świadczeń w oderwaniu od konkretnej postaci szkody na osobie (na przykład uszczerbku na zdrowiu, rozstroju zdrowia, niezdolności do pracy), powstałej w warunkach determinujących uzyskanie statusu działacza opozycji antykomunistycznej lub osoby represjonowanej jest, jak sądzę, nie tyle zaprzeczeniem odszkodowawczego charakteru przedstawionych świadczeń, ile wyrazem dostrzeżenia przez ustawodawcę, już na etapie tworzenia prawa, trudności w jej generalnym oszacowaniu i ujęciu w ogólne formuły prawne lub jej wykazania w razie ujęcia jej w te formuły, ze względu na jej źródło w odległych w czasie zdarzeniach, objętych ochroną prawną po wielu latach od ich zaistnienia.

30 Zob. J. Jończyk, Prawo zabezpieczenia społecznego, Kraków 2001, s. 16-17, 168-169.

31 Zob. art. 73 ustawy z dnia 17 grudnia 1998 r. o emeryturach i rentach z Funduszu Ubezpieczeń Społecznych, tekst jedn. Dz.U. z 2021 r. poz. 291. 


\section{Bibliografia}

Jończyk J., Prawo zabezpieczenia społecznego, Kraków 2001.

Klementowski R., Skazani na uran. Kopalnie rud uranu we wspomnieniach żotnierzy batalionów pracy, „Studia nad Autorytaryzmem i Totalitaryzmem” 31, 2009.

Macała J., Oceny komunizmu w polskiej refleksji politycznej lat 1989-1993, „Studia nad Autorytaryzmem i Totalitaryzmem" 33, 2011.

Nitecki S., Prawo do pomocy społecznej w polskim systemie prawnym, Warszawa 2008.

Rodak L., Solidaryzm i/jako obiektywizm, [w:] Idea solidaryzmu we wspótczesnym prawie konstytucyjnym, red. A. Łabno, Warszawa 2015.

Sanetra W., Aksjologiczne podstawy prawa ubezpieczeń spolecznych, [w:] Ubezpieczenie spoleczne w procesie zmian. 80 lat Zakładu Ubezpieczeń Społecznych, Warszawa 2014.

Sierpowska I., Prawo pomocy społecznej, Kraków 2006.

Ślebzak K., Prawo do zabezpieczenia społecznego w Konstytucji RP. Zagadnienia podstawowe, Warszawa 2015.

Sobolewski J.P., Prawo kombatanckie w Polsce i za granica, Warszawa 2005.

Stopka K., Świadczenia odszkodowania socjalnego w prawie polskim, Warszawa 2018.

Stopka K., Zasada subsydiarności w prawie pomocy społecznej, Warszawa 2009.

Szurgacz H., Prawo socjalne w latach 1989-1999. Kilka uwag o kierunkach rozwoju, [w:] Prawo pracy a wyzwania XXI w. Księga Jubileuszowa Profesora Tadeusza Zielińskiego, red. M. Matey-Tyrowicz, L. Lawacki, B. Wagner, Warszawa 2002.

Szurgacz H., Wstęp do prawa pomocy społecznej, Wrocław 1992.

Zacher H.F., Rozwój zabezpieczenia społecznego w Europie, [w:] Ład społeczny w Polsce i Niemczech na tle jednoczacej się Europy, red. M von Bernd, T. Zieliński, Warszawa 1999.

Zarys problematyki prawa kombatanckiego i organizacji kombatanckich w II Rzeczypospolitej, Kancelaria Senatu Biuro Analiz i Dokumentacji, Dział Analiz i Opracowań tematycznych, Opracowania Tematyczne OT-586, lipiec 2010, www.senat.gov.pl.

Ziembiński Z., Wartości konstytucyjne. Zarys problematyki, Warszawa 1993.

Wyrok WSA w Gorzowie Wielkopolskim z dnia 22 stycznia 2020 r., II SA/Go 447/19, LEX nr 2775510.

Wyrok WSA we Wrocławiu z dnia 17 października 2019 r., IV SA/Wr 172/19, LEX nr 2742413.

Wyrok WSA w Łodzi z dnia 23 października 2019 r., II SA/Łd 427/19, LEX nr 2741081. 